\section{AN OVERVIEW ON TURNING PROCESS}

\author{
Monika Saini, Ravindra Nath Yadav*, Sunil Kumar \\ *Corresponding Author: Department of Mechanical Engineering, \\ BBD National Institute of Technology and Management, Lucknow-226028, India \\ Email: rnymnnit@yahoo.com,mechrny@gmail.com
}

\begin{abstract}
Turning is one of the most popular convectional machining processes to remove the extra material from the rotating surfaces. In this process, a wedge shaped cutting tool penetrated toward the workpiece and removed the extra material in the form of chips. Almost all known materials can be machined by this process in different forms like external turning, internal turning, plain/cylindrical turning, step turning, taper turning, face turning etc. with selection of appropriate cutting tool for particular material. The aim of the present study is to summarize a report on the turning process including present and past research works. This paper present a brief overview on turning operation considering the different aspects and focus the future scopes of works in the same area, which is beneficial for the researches who work in the same field.
\end{abstract}

Keywords—cutting; composite; finishing; machining; material; surface; tool, turning

\section{INTRODUCTION}

Turning is the primary metal cutting process in most of the production industries to get the critical features with specific surface finish [1]. In this process, a wedge shaped single point cutting tool penetrates toward the rotating workpiece and material is removed in form of chips as shown in the Fig. 1. The basic purposes of the turning process are to reduce the diameter of workpiece, get the specified dimensions and produce a smooth surface [2]. Generally, it is used to machine external as well as internal surfaces of cylindrical workpiece in term of plain turning, taper turning, step turning and face turning. In some cases, it is used to produce gears, cams, shafts, axels and other components also [3].

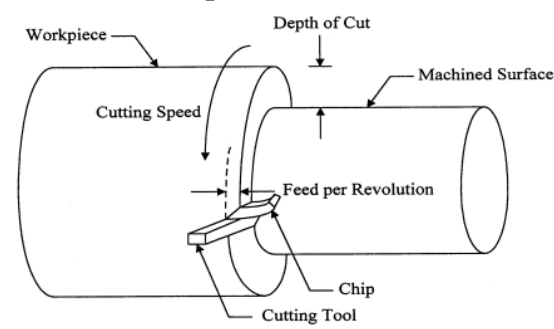

Fig. 1. Turning operation [4]

The metal cutting is one of the important and widely accepted machining method to meet the demands of industries. Generally, the performances of cutting technology depend on the cutting tools geometry, tool materials, cutting parameters and efficiency of the process [5-7]. It is used for machining of most of the materials including ferrous, non-ferrous metal and their alloys, heat treated metals and alloys, ceramics and composites etc. Due to the importance of turning, researchers always make effort to improve the efficiencies of the process to get the desired quality of products at low cost. The aim of the present paper is also an effort in that direction.

\section{RESEARCH AND DEVELOPMENT IN TURNING}

In this section, the published works related to the turning process used in machining of different materials like steel and their alloy, cast iron, titanium alloy, Inconel, metal matrix composites (MMCs) etc. are summarized and discussed.

\section{A. Research in Turning of Ferrous Metas and their Alloys}

Ferrous metals and its alloys are most popular commercial material used in many engineering applications. Many researchers were focused their studied on turning of these materials with application of different cutting tool materials. Ueda et al. [8] investigated that cutting temperature is highly affected by cutting speed while negligible effect of feed rate and depth of cut during turning of different steel alloys with cubic born nitrate (CBN) cutting tool. Sahin and Motorcu [9] investigated the machining characteristics of the mild steel with coated carbide cutting tool. They observed that cutting speed and feed rate were highly influenced on the surface finish. Suhail et al. [10] also worked on turning of the mild steel and optimized the controlled parameters using grey relational analysis (GRA) technique.

$\mathrm{Li}$ and Liang [11] focused their research in near dry and dry conditions during cutting of AISI 1050 steel with uncoated carbide tool and found lower cutting force with near dry as compared to the dry condition. Asilturk and Akkus [12] also studied on dry turning during machining of AISI 4140 steel with coated carbide tool and claimed that surface finish highly influenced by feed rate. Mandal et al. [13] found that the depth of cut has maximum effect on the tool wear during turning of the AISI 4340 steel with zirconium-alumina tool. The effects of lubricant with other turning parameters were investigated by Abhang and Hameeddullah [14] during machining of steel with tungsten carbide tool. They claimed that surface finish was improved with application of lubricant. The surface roughness also affected by tool nose radius and decreases with increase in the nose radius of the cutting tool [15]. The application of graphite powder as a solid lubricant during turning of AISI 1040 steel was tested by Srikiran et al. [16]. They observed that cutting forces increase with decrease in particles size whereas surface finish deteriorates due to the size of the solid graphite particles. 


\section{(2) \\ ELK \\ Asia Pacific Journals}

\section{B. Research in Turning of Cast Iron}

Cast iron (CI) is also an important material of iron families that shows high hardness, high wear, temperature and corrosion resistance [17-19]. It is widely used in mining, power, cement, coal-coke, steel and foundry industries [20]. However, the machining of CI becomes difficult due to the high hardness and high tool wears. Ezugwu and Tang [21] found that the round shaped cutting tool gives better surface finish with low damages as compared to the rhomboid shaped tool during turning of the CI (G-17) with ceramic tool. Even though, very poor cutting ability of ceramic tool was obtained during turning of the nodular cast iron [22].

A comparative studies between dry and air-cooled turning of grey cast iron with oxide added ceramic tool was carried out by Sarma and Dixit [23]. They found lower cutting force and better surface finish with air cooled turning as compared to the dry turning as shown in Figs. 2(a)-(b). Several researchers investigated that multilayer coated tool performed better as compared to the uncoated tool $[24,25]$. Souza et al. [26] tested the performances of silicon nitride based ceramic tool during turning of the grey $\mathrm{CI}$ and found high tool life. Gunay and Yucel [26] carried out experiments on white nickel based white CI with CBN cutting tool and optimized the surface roughness with the help of Taguchi technique.
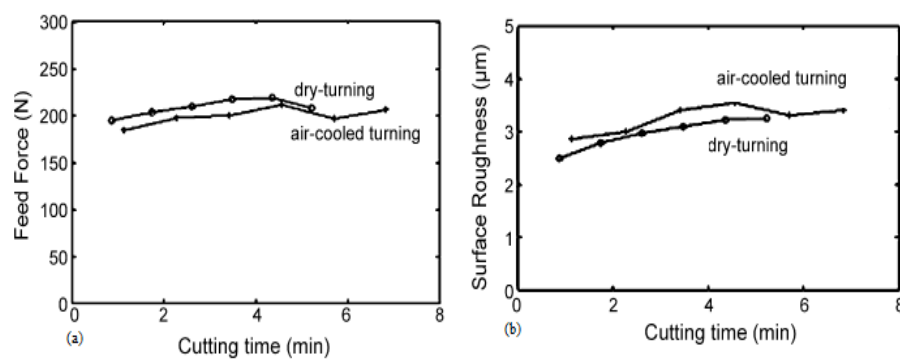

Fig. 2. Effects of dry and air cooled turning on force and surface roughness at cutting speed $=100 \mathrm{~m} / \mathrm{min}$, feed $=0.16 \mathrm{~mm} / \mathrm{rev}$ and depth of cut $=1.5 \mathrm{~mm}$ [23]

\section{Research in Turning of Inconel 718}

Inconel 718 is nickel-iron based heat resting super alloy. It has wide application in field of aerospace, nuclear, space vehicles, submarines, power plants, oil and petrochemical industries due to the their superior high temperature mechanical properties [27, 28]. The turning of Inconel 718 is now a challenge for manufacturing engineers due to the poor thermal property, high temperature strength, work hardening tendency and high tool-workpiece affinity [29]. Thus, the researchers focus their studies to machine Inconel effectively by controlling the tool material, tool geometry and cutting conditions. The other associated problem is detaching of carbide particle with cutting tool [30]. The major problem during turning of Inconel is work hardening of turned surface refers to the elongation in grains structure as a result tearing phenomenon takes place as shown in the Fig. 3 .

\section{ELK Asia Pacific Journals - Special Issue} ISBN: 978-81-930411-4-7

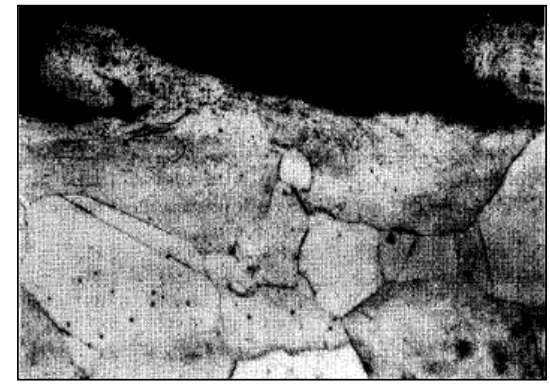

Fig. 3. Tearing on turning surface of Inconel 718 [21]

Many researchers focus their studies to improve the machining capabilities of Inconel 718. Arunachalam et al. [31] suggested that coated carbide cutting tool in round shape with chamfered cutting edge, negative rake and small nose radius has been better combination for turning of the Inconel 718 . Satyanarayana et at. [32] optimized the cutting speed, depth of cut and feed rate to minimize the cutting force, surface roughness and tool wear with application of the Taguchi-GRA hybrid techniques for turning of Inconel 817 with application of the uncoated carbide cutting tool.

\section{TURNING OF NON-FRROUS METALS}

The present section summarized a review report on the turning of the non-ferrous metals including titanium alloys and composites. The analysis of published papers are presented and discussed after careful studies.

\section{A. Research in Turning of Titanium Alloys}

Titanium is the commercial name of the Ti-6Al-4V alloy. It is widely used in aerospace industries due to the superior mechanical properties. It is highly demanding in the military and commercial aircraft [33]. It is generally used for a component which requires higher reliability with constant surface finish [34]. Even though, it low thermal conductivity makes difficulties in machining. Nabhani [35] claimed that very high temperature generated near to cutting edge of tool as a result plastic deformation occurs. Hascahk and Caydas [36] were concluded that feed rate and cutting speed are highly influenced on surface finish and tool life. They also concluded that surface roughness was slightly affected by cutting speed while depth of cut was highly affected the tool life.

\section{B. Research in Turning of Metal Matrix Composites}

Metal matrix composites (MMCs) are newly advanced engineering materials used in field of automobiles, aerospaces, railways, computers, robotics, sports etc. due to the their unique properties like light in weight, high specific strength, good wear resistance and low thermal coefficient [37-41]. Generally, MMCs are consisting two distinct phases as matrix and reinforcements. The turning of MMCs leads to high tool wears due to presence of the reinforcements [37, 41-42]. Even though, sometimes graphite powers are used to enhance the machinability of these materials [43, 44].

Generally, diamond or diamond coated cutting tools are used for machining of the MMCs but they are very costly. During diamond turning of the MMCs, the reinforced particles 


\section{(2) \\ ELK \\ Asia Pacific Journals}

either pulled out or cut through and lead to the poor surface finish of turned surfaces [45]. This phenomenon has been shown in the Fig. 4. Several researchers were compared the performances of poly crystalline diamond (PCD) cutting tool with chemically vapour coated diamond (CVCD) cutting tools during turning of different composites materials like aluminium silicon carbide $(\mathrm{Al} / \mathrm{SiC})$ and aluminium-alumina $\left(\mathrm{Al} / \mathrm{Al}_{2} \mathrm{O}_{3}\right)$ and investigated that the coating on tool surface was worn out rapidly due to the abrasion action between tool and workpiece as a result very short tool life and rapid tool fracture [46, 47]. Ding et al. [48] compared the performances of PCD cutting tool with polycrystalline cubic boron nitride (PCBN) tools. They found that the PCD cutting tools showed better performances than PCBN cutting tools due to the higher abrasion and fracture resistance with lower adhesion property with the workpiece material.

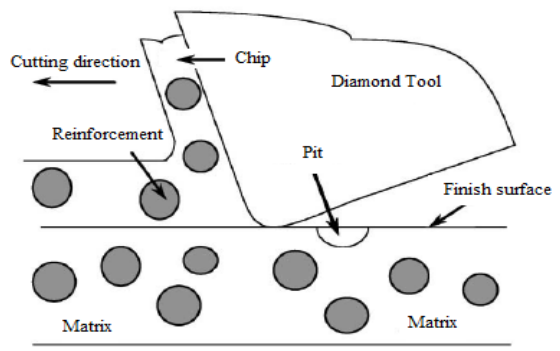

Fig. 4. Turning of MMCs with pit formation [45]

Due to the wide applicabilities and difficulties in machining of the MMCs, researchers are always made their effort to know the machining capabilities of low cost cutting tool materials for machining of these difficult to machine materials. In this way, the performances of cubic boron nitride (CBN) cutting tool were studied by Ciftci et al. [49]. They experimentally proved that the tool wear (flank wear) was highly influenced by size of the reinforced particles. They also investigated that the $\mathrm{Al} / \mathrm{SiC}$ composite reinforced with particle size $110 \mu \mathrm{m}$ shown poor machinability and leads to high facture at cutting edge and nose radius as shown in the Fig. 5. Aramesh et al. [50] also studied the machining performances of $\mathrm{CBN}$ cutting tool during machining of the aluminiumtitanium carbide $(\mathrm{Al} / \mathrm{TiC})$ composite.

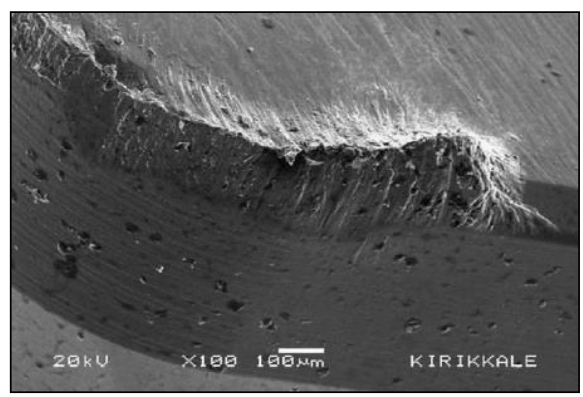

Fig. 5. Flank wear during turning of $\mathrm{Al} / \mathrm{SiC}$ withCBN tool [49]

\section{HARD TURNING PROCESS}

The researchers and developers always focus to develop new approaches to fulfil the requirements of the industries without any loss in the characteristics of existing system. Hard
ELK Asia Pacific Journals - Special Issue

ISBN: 978-81-930411-4-7

turning is the one of them, which is used to replace the grinding operations with effective application of the very hard cutting tools like ceramics and CBN. These cutting tools are capable to turn high harded steels having hardness greater than 45 HRC without any application of cutting fluid/coolant on a highly rigid lathe machine tool. This process has been developed as an alternative to the grinding process in term of reduction in setup changes, product cost and lead time without loss in the surface quality of the products [51, 52]. It shows many advantages over grinding process like high metal removal, easily applicable at existing (lathe) machine, ability to machine thin wall sections with low cutting forces and eliminates the requirement of coolant [53.]

\section{A. Research in Area of Hard Turning}

Even though, hard turning process having a lot of merits but cannot replace the grinding process due to the difficulties to achieve the high surface quality. To meet such challenges, further developments are required in the same field. Pavel et al. [53] shown that the machined surface highly affected by flank wear of cutting tool during hard turning of the hardened steel (1117-steel) with CBN cutting tool. Aslan [54] compared the performances of $\mathrm{CBN}$ cutting tool with coated cermet and ceramic cutting tools during turning of the cold-work tool steel $(\mathrm{X} 210 \mathrm{Cr} 12)$. They experimentally proved that CBN tool shown better performances i.e. flank wear and surface finish as compared to the other cutting tools. The effect of tool materials on flank wear with different cutting tool materials has been shown in the Fig. 6 .

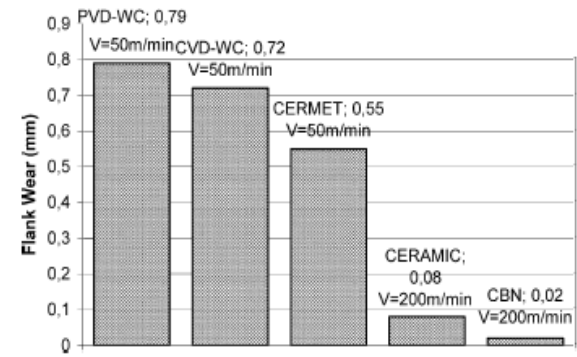

Fig. 6. Effect of tool materials on flank wear [54]

To achieve the better machinability, the CBN cutting tools were tested in different conditions. Diniz and Oliveira [55] tested the performances of CBN tools (low CBN content and high $\mathrm{CBN}$ content i.e. 7020, 7052) during hard turning of the AISI 4340 steel (56 HRC) in continuous, semi continuous and intercepted turning with chamfered and round cutting edge. They found that high grade CBN gave longer tool life as compared to the low grade CBN cutting tool. They also observed that chamfered edge cutting tool provided longer tool life during continuous turning. Oliveira et al. [56] shown that the CBN cutting tool gave better surface finish as compared to whisker-reinforced cutting tools during hard turning of the continuous and interrupted cutting. Katuku [57] suggested that the shear localization within the primary and secondary shear zones are responsible for the wear rate of the cutting tool during turning of the ASTM grade-2 austempered ductile iron (ADI) with $\mathrm{CBN}$ cutting tool. 


\section{(2) \\ ELK \\ Asia Pacific Journals}

Several researchers tested the machining capability of carbide cutting tools in hard turning process. Bartarya and Choudhury [58] was used uncoated carbide cutting tool during hard turning of the harded EN-31 steel (equivalent to steel of AISI 52100 grade) and analysed. They claimed that depth of cut and feed rate were most significant parameters that affect the cutting forcess. Chinchanikar and Choudhury [59] compared the performances of the physical vapour deposited single layer TiAlN coated carbide cutting tool with chemical vapour deposited multilayer TiCN/Al2O3/TiN coated carbide cutting tool during turning of hardened AISI 4340 steel (3335 HRC). They found that tool life was highly affected by cutting speed, which is followed by depth of cut and feed rate. The cutting speed and feed rate were also influencing the tool wear (flank wear) during hard turning of the AISI D3 steel (58HRC) turned with coated carbide cutting tool [60].

\section{Modeling AND OPTIMIZATION OF TURNING PROCESS}

Modelling is required to know the process behaviour and scientific study of a system based on experimental or theoretical analysis $(61,62)$. The theoretical modeling is more economical as compared to the experimental because of no need of experiments. Generally, to develop a mathematical relation between input and output parameter in term of equations is known as modelling. Due the complexity in the turning process, most of the researchers were developed experimental model in different turning conditions.

Optimization can be defined as maximum or minimum value of the objectives, which refers deterioration in the optimum value with any changes in the input conditions. Many statistical as well as soft computing techniques are used to optimize the parameters of different processes [63-66]. The basic needs of optimization are to get the better responses at low production cost. Generally, modeling and optimization are simultaneously applied to get the better results.

\section{A. Research in Modeling of Turning Process}

Due to the complexity in turning, most of the mathematical models were developed based on the experimental observations. Choudhury and Baradie [67] developed a second order mathematical model to predict the tool wear with any changes in cutting speed, feed rate and depth of cut. Several researchers were compared the prediction capability of regression model with artificial neural network (ANN) model and found good prediction with ANN model [68-70]. Ozel et al. [71] also found better performance with ANN model as compared to the mathematical model during analysis of tool wear and surface roughness with varying conditions of control parameters. Gupta [72] found that ANN and support vector regression (SVR) models were performed better as compared to the regression and response surface model (RSM).

\section{B. Research in Optimization of Turning Process}

Many researchers optimized the control parameters of turning process to get the better result. Yang and Tarng [4] optimized the process parameters to minimize the tool wear rate using Taguchi approach. Several researchers were also used Taguchi technique to optimize the turning parameters
ELK Asia Pacific Journals - Special Issue ISBN: 978-81-930411-4-7

like cutting speed, feed and depth of cut for performance measures like tool life, cutting force and surface finish [12, 14, 26, 53, 73-75]. Nalbant et al. [75] optimized the nose radius, feed rate, and depth of cut to minimize the surface roughness for turning of the AISI 1030 steel with Taguchi technique.

The application of Taguchi-GRA hybrid optimization technique was also tested in turning [32]. RSM and Taguchi Techniques for modeling and optimization of the parameters were tested by several researchers [78, 79]. The application of GRA optimization technique also tested to optimize the process parameters [10]. The application genetic algorithm in turning process are also tested by several researchers to optimize the process parameters and get a lot of optimal solution within the range of selected parameters, which provided additional facilities to manufacturer to set the input turning conditions according to the available resources or as per design requirements [2, 79-80].

\section{PROCESS PARAMETERS AND PERFORMANCE MEASURES}

Turning is complex metal cutting process, in which lot of factors (controllable or non-controllable) directly or indirectly affecting the performances. The process and performance parameters related to the turning are shown in the Fig. 7.

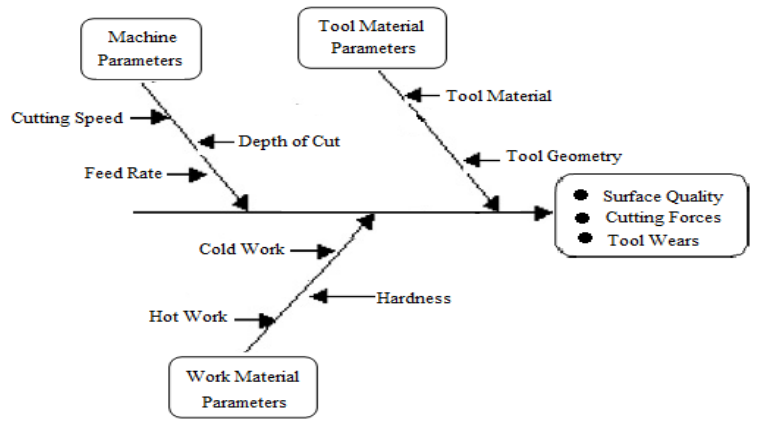

Fig. 7. Process and performance parameters of turning process

The performance measures (surface quality, forces, tool wears) depend upon various parameters like machine parameters, materials (tool and workpiece). The review of research works show that tool wear is high affected by cutting speed and followed by feed rate and depth of cut [67]. Even though, increase in cutting speed, feed rate or depth of cut does influence the surface finish [22]. The feed rate and cutting speed were found most influential factors that affect the surface quality and tool life [32, 36]. The tool life also found poor with coated tool due to high flank wear after coating rupture [47]. As compared to the coated tool, the uncoated tool gave better surface finish and high tool wear [81]. On other hand, multi-layer coated cutting tool gives better performances in all the respects [24].

The workpiece hardness is also responsible for products quality because the hardness responsible for poor finish and tool wears [69]. The coating materials of cutting tools are also responsible for quality machining, such phenomenon analysed by Aslan [54]. Sarma and Dixit [23] investigated that air cooled turning gives better surface finish with low tool wear as compared to the dry turning. Cutting tool geometry is also 


\section{(2) \\ ELK \\ Asia Pacific Journals}

responsible to cutting. The round shape coated (chamfered cutting edge) tool with negative rake and small nose radius has been better option for turning of the Inconel 718 [31].

\section{SUMMARY AND FUTURE SCOPE OF WORKS}

In present paper, a summary on the published research has been summarized. It has been found that turning is a good metal cutting method to get the desired shape. Advancement in technology, the cutting of the difficult to machine materials are also possible with application of high strength cutting tool like ceramic, carbide, $\mathrm{CBN}$ and diamond. Even though, the diamond cutting tools are not suitable for turning of the ferrous metals. Development of the high speed cutting tools materials, the turning process is capable to replace the grinding operation with effective application of the hard turning in dry condition. However, lot of research are required in field of hard turning process. It has been also analyzed that most of work related to the studies of the effects of cutting speed, depth of cut and feed rate on performance measures. A little bit effort has made in area of tool geometry, turning of complex profile and interrupted surfaces. That area requires more effort to meet the future demand by turning.

Modeling and optimization are another vital conditions to achieve the goal. Literature review shows that most of the modeling/optimization made by statistical techniques and a little effort has been made in area of soft computing while it shows more advantages over statistical methods. Thus, that area also needs more attention to meet the future challenges.

Finally, an exhaustive review on turning process is presented, which is beneficial for the researchers who work in the same field. It is also beneficial to analyze the present and past work related to the turning process.

\section{References}

[1] J. P. Davim, V.N. Gaitonde and S.R. Karnik, "Investigations into the effect of cutting conditions on surfaceroughness in turning of free machining steel by ANN models," J. Mater. Process. Technol., vol. 205, pp. 16-23, 2008.

[2] A.R. Yildiz, "A comparative study of population-based optimization algorithms for turning operations," Inform. Sci., vol 210, pp. 81-88, 2012.

[3] W. Grzesik, "Influence of tool wear on surface roughness in hard turning

using differently shaped ceramic tools," Wear, vol. 265, pp. 327-335, 2008.

[4] W.H. Yang and Y.S. Tarng, "Design optimization of cutting parameters for turning operations based on the Taguchi method," J. Mater. Process. Technol., vol. 84, pp. 122-129, 1998.

[5] I. Mukherjee and P. K. Ray, "A review of optimization techniques in metal cutting processes," Comp. Indust. Eng., vol. 50, 15-34, 2006.

[6] X.D. Fang, "Experimental investigation of overall machining performance with overall progressive tool wear at different tool faces," Wear, vol. 173, 171-178, 1994.

[7] M.C. Shaw, Metal Cutting Principles, Oxford University Press, New

York, 1984.

\section{ELK Asia Pacific Journals - Special Issue}

ISBN: 978-81-930411-4-7

[8] T. Ueda, M.A. Huda, K. Yamada and K. Nakayama, "Temperature measurement of $\mathrm{CBN}$ tool in turning of high hardness steel," Ann. CIRP, vol. 48, pp. 63-66, 1999.

[9] Y. Sahin and A.R. Motorcu, "Surface roughness model for machining mild steel with coated carbide tool," Mater. Design, vol. 26, pp. 321-326, 2005.

[10] A.H. Suhail, N. Ismail, S.V. Wong and N.A.A. Jalil, "Surface roughness identification using the grey relational analysis with multiple performance characteristics in turning operations," Arab. J. Sci. Eng., vol. 37, pp. 1111$1117,2012$.

[11] K.M. Li and S.Y. Liang, "Modeling of cutting forces in near dry machining under tool wear effect," Int. J. Mach. Tools Manuf., vol. 47, pp. 1292-1301, 2007.

[12] I. Asiltürk and H. Akkus, "Determining the effect of cutting parameters on surface roughness in hard turning using the Taguchi method," Measurement, vol. 44, 16971704, 2011.

[13] N. Mandal, B. Doloi, B. Mondal and Reeta Das, "Optimization of flank wear using Zirconia Toughened Alumina (ZTA) cutting tool: Taguchi method and regression analysis," Measurement, vol. 44, 2149-2155, 2011.

[14] L.B. Abhang and M. Hameeddullah, "Optimization of machining parameters in steel turning by Taguchi method."Procedia Eng., vol. 38, 40-48, 2012.

[15] A.J. Makadia and J.I. Nanavati, "Optimisation of machining parameters for turning operations based on response surface methodology," Measurement, vol. 46, 1521-1529, 2013.

[16] S. Srikiran, K. Ramji, B. Satyanarayana and S.V. Ramana, "Investigation on turning of AISI 1040 steel with the application of nano-crystalline graphite powder as lubricant," Proc. IMechE Part C: J. Mech. Eng. Sci., vol. 228, pp. 1570-1580, 2013.

[17] E. Yucel1 and M. Gunay, "Modelling and optimization of the cutting

conditions in hard turning of high-alloy white cast iron (Ni-Hard)," Proc. IMechE Part C: J. Mech. Eng. Sci., vol. 227, pp. 2280-2290, 2012.

[18] W.D. Callister, Material Science and Engineering an Introduction, $6^{\text {th }}$ ed. Wiley India, New Delhi, 2006.

[19] M. P. Groover, Fundamentals of Modern Manufacturing: Materials, Processes, and Systems, $2^{\text {nd }}$ ed., John Wiley and Sons, New Delhi, 2005.

[20] K. Rohrig, Ni-Hard Material Data and Applications, Nickel Development Institute, Canada, 1996.

[21] E.O.Ezugwu and S.H. Tang, "Surface abuse when machining cast iron (G-17) and nckel based super alloy (Inconel 718) with ceramic tool," J. Mater. Process. Technol., vol. 55, pp. 63-69, 1995.

[22] A.K. Ghani, I.A. Choudhury and Husni, Study of tool life, surface roughness and vibration in machining nodular cast iron with ceramic tool," J. Mater. Process. Technol. Vol. 127, pp.17-22, 2002

[23] D.K. Sarma and U.S. Dixit, "A comparison of dry and aircooled turning of grey cast iron with mixed oxide ceramic tool," J. Mater. Process. Technol. vol. 190, 160-172, 2007.

[24] R. Yigit, E. Celik, F. Findik and S. Koksal, "Tool life performance of multilayer hard coatings produced by HTCVD for machining of nodular cast iron," Int. J. Refract. Metals Hard Mater., vol. 26, 514-524, 2008.

[25] W. Grzesik, J. Rech, K. Zak and C. Claudin, "Machining performance of pearlitic-ferritic nodular cast iron with coated carbide and silicon nitride ceramic tools," Int. J. Mach. Tools Manuf., vol. 49, pp. 125-133, 2009. 


\section{(2) \\ ELK \\ Asia Pacific Journals}

[26] M. Gunay, E. Yucel, "Application of Taguchi method for determining optimum surface roughness in turning of high-alloy white cast iron," Measurement, vol. 46, pp. 913-919, 2013.

[27] E.O. Ezugwu, Z.M. Wang and C.I. Okeke, "Tool life and surface integrity when machining Inconel 718 with PVD and CVD coated tools," Tribol. Trans., vol. 42, pp. 353$360,1999$.

[28] E.O. Ezugwu, Z.M. Wang and A.R. Machado, "The machinability of nickel-based alloys: a review," J.Mater. Process. Technol., vol. 86, pp. 1-16, 1999.

[29] M.C. Shaw, Metal Cutting Principles, Clarendon Press, Oxfort, 1984.

[30] Y.S. Liao and R.H. Shiue, "Carbide tool wear mechanism in turning of Inconel 718 superalloy," Wear, vol. 193, pp. 16-24, 1999.

[31] R.M. Arunachalam, M.A. Mannan and A.C. Spowage, "Residual stress and surface roughness when facing age hardened Inconel 718 with CBN and ceramic cutting tools," Int. J. Mach. Tools Manuf., vol. 44, 879-887, 2004.

[32] B. Satyanarayana, B.R. Janardana, D.H.Rao, “Optimized high speed turning on Inconel 718 using Taguchi method base graey relational analysis," Ind. J.Eng. Mater. Sci., vol. 20, pp.269-275,2013.

[33] M. Ramulu, T. Branson and D. Kim, "A study on the drilling of composite and titanium stacks," Compos. Struct., vol. 54, pp.67-77, 2001.

[34] C.H.C. Haronand A. Jawaid, "The effect of machining on surface integrity of titanium alloy Ti-6Al-4V," J. Mater. Process. Technol., vol. 166, pp. 188-192, 2005.

[35] F. Nabhani, "Machining of aerospace titanium alloys," Robot. Comput. Integ. Manuf., vol. 17, pp. 99-106, 2001.

[36] A. Hascahk and U. Caydas, "Optimization of turning parameters for surface roughness and tool life based on the Taguchi method," Int. J. Adv. Manuf. Technol., vol. 38, pp.896-903, 2008.

[37] R. N. Yadav, V. Yadava and S.K.S.Yadav, "Production and processing of metal matrix composites (MMCs): challenges and opportunities," Proc. All Ind. Semin. Adv.Mater. Mater. Select. Design (AMMSD-2012), Harcourt Butler Technological Institute, Kanpur, India, pp. 122-132, 2012.

[38] M. M. Schwartz, Composite Material Handbook, McGraw-Hill Book Company, New Delhi, India, 1983.

[39] S. K. Mazumdar, Composites Manufacturing, Material, Product and Process Engineering, CRC Press, LLC, N.W. Boca Raton, Florida, 2000.

[40] J. P. Davim, Machining of Metal Matrix Composites, Springer London Dordrecht Heidelberg New York, 2012.

[41] R.K. Garg, K.K. Singh, A. Sachdeva, V.S. Sharma, K. Ojha and S. Singh, "Review of research work in sinking EDM and WEDM on metal matrix composite materials," Int. J. Adv. Manuf. Technol.,vol. 50, pp. 611-624, 2010.

[42] R.N. Yadav, V. Yadava and K.B. Judal, "Machining of metal matrix composites (MMCs) using simultaneous influence of abrasion and spark erosion: a combined approach," Proc. $7^{\text {th }}$ Int. conf. Precis. Meso Micro Nano Eng. (COPEN-7), College of Engineering, Pune, India, pp 353-358, 2011

[43] R.N. Yadav, V. Yadava, "Experimental study of erosion and abrasion based hybrid machining of hybrid metal matrix composite," Int. J. Precis. Eng. Manuf., vol. 14, pp. 1293-1299, 2013.

[44] R.N. Yadav, V. Yadava, "Machining performance of slotted-electrical discharge diamond face grinding of Al/SiC/Gr composite," Mater. Manuf. Process., vol. 29, pp. 585-592, 2014.
ELK Asia Pacific Journals - Special Issue ISBN: 978-81-930411-4-7

[45] K.C. Chan, C.F. Cheung, M.V. Ramesh, W.B. Lee and S To, "A theoretical and experimental investigation of surface generation in diamond turning of an Al6061/SiCp metal matrix composite," Int. J. Mech. Sci., vol. 43, pp. 2047-2068, 2001

[46] G.E. Errico and R. Calzawarini, "Turning og metal matrix composites," J. Mater. Process. Technol., vol. 119, pp. 257-260, 2001.

[47] J. P. Davim, "Diamond tool performance in machining metal-matrix composites," J. Mater. Process. Technol., vol. 128, pp. 100-105, 2002.

[48] X. Ding, W.Y.H. Liew and X.D. LiuK, "Evaluation of machining performance of MMC with PCBN and PCD tools," Wear, vol. 259, 1225-1234, 2005.

[49] I. Ciftci, M. Turker and U. Seker, "CBN cutting tool wear during machining of particulate reinforced MMCs," Wear, vol. 257, pp. 1041-1046, 2004

[50] M. Aramesh, B. Shi, A.O. Nassef, H. Attia, M. Balazinski and H.A. Kishawy, "Meta-modeling optimization of the cutting process during turningtitanium metal matrix composites (Ti-MMCs)," Procedia CIRP, vol. 8, pp. 576$581,2013$.

[51] T. Hodgson, P. Trendler and G. Ravignani, "Turning hardened tool steels with cubic boron nitride inserts," Ann. CIRP, vol. 30, pp. 63-66, 2001.

[52] W. Konig, R. Komanduri, H. Tonshoff and G. Ackershott, "Machining of hard materials," Ann. CIRP, vol. 33, pp. 417-428, 1984.

[53] L. Pavel, I. Marinescu, M. Deis, J. Pillar, "Effect of tool wear on surface finish for a case of continuous and interrupted hard turning," J. Mater. Process. Technol., vol. 170, pp. 341-349, 2005 .

[54] E. Aslan, "Experimental investigation of cutting tool performance in high speed cutting of hardened X210 Cr12 cold-work tool steel (62 HRC)," Mater. Design, vol. 26, pp. 21-27, 2005.

[55] A.E. Diniz and A.J. Oliveira, "Hard turning of interrupted surfaces using CBN tools," J. Mater. Process. Technol., vol. 195, pp. 275-281, 2008.

[56] A.J. Oliveira, A.E. Diniz, D.J. Ursolino, "Hard turning in continuous and interrupted cut with PCBN and whiskerreinforced cutting tools," J. Mater. Process. Technol.,vol. 209, 5262-5270, 2009 .

[57] K. Katuku, A. Koursaris and I. Sigalas, "Wear, cutting forces and chip haracteristics when dry turning ASTM Grade 2 austempered ductile iron with PcBN cutting tools under finishing conditions," J. Mater. Process. Technol.,vol. 209, pp. 2412-2420, 2009.

[58] G. Bartarya1 and S.K Choudhury, "Influence of machining parameters on forces and surface roughness during finish hard turning of EN 31 steel," Proc. IMechE Part B: J. Eng. Manuf. vol. 228, pp. 1068-1080, 2014

[59] S. Chinchanikar and S.K Choudhury, "Experimental investigations to optimise and compare the machining performance of different coated carbide inserts during turning hardened steel," Proc. IMechE Part B: J. Eng. Manuf. vol. 228, pp. 1104-1117, 2014.

[60] J.S. Dureja, R. Singh and M.S. Bhatti, "Optimizing flank wear and surface roughness during hard turning of AISI D3 steel by Taguchi and RSM methods," Product. Manuf. Resear., vol. 2, pp. 767-783, 2014

[61] T.H. Duong, H.C. Kim and D.Y. Lee, "Selection of machining conditions for microchannels in ultraprecision diamond turning," Proc. IMechE Part B: J. Eng. Manuf., vol. 227, pp. 1558-1570, 2013

[62] R.N. Yadav, V. Yadava and G.K. Singh, "Modeling and simulation of spark sssisted diamond face grinding of 


\section{Asia Pacific Journals}

Tungsten Carbide-Cobalt composite," Int. J. Manuf. Technol. Manag., vol. 28, pp. 132-145, 2014.

[63] R.N. Yadav and V. Yadava, "Intelligent modeling and prediction of slotted electrical discharge diamond grinding (S-EDDG) of aluminium-silicon carbidegraphite composite", Int. J. Abras. Technol., vol. 6, pp 93106, 2013.

[64] P.K Shrivastava and A.K. Dubey, "Electrical discharge machining-based hybrid machining processes: a review," Proc. IMechE Part B: J. Eng. Manuf., vol. 228, pp. 799825, 2013.

[65] R.N. Yadav and V. Yadava, "Multi-objective optimization of slotted electrical discharge abrasive grinding of metal matrix composite using artificial neural network and non-dominated sorting genetic algorithm," Proc. IMechE Part B: J. Eng. Manuf., vol. 227, pp 14421452, 2013.

[66] R.N. Yadav, V. Yadava and G.K. Singh, "Multi-objective optimization of process parameters in electro-discharge diamond face grinding based on NN-NSGAII hybrid technique," Fron. Mech. Eng., vol. 8, pp.319-332, 2013.

[67] I.A. Choudhury and M.A.E. Baradie, "Tool-life prediction model by design of experiments for turning high strength steel (290 BHN)," J. Mater. Process. Technol., vol 77, pp. 319-326, 1998.

[68] W.S. Lin, B.Y. Lee and C.L. Wu, "Modeling the surface roughness and cutting force for turning," J. Mater. Process. Technol., vol. 108, pp. 286-293, 2001.

[69] T. Ozel and Y. Karpat, "Predictive modeling of surface roughness and tool wear in hard turning using regression and neural networks," Int. J. Mach. Tools Manuf., vol. 45, pp. 467-479, 2005.

[70] J.Y. Zhang, S.Y. Liang, G. Zhang and D. Yen, "Modeling of residual stress profile in finish hard turning," Mater. Manuf. Proces., vol. 21, pp. 39-45, 2006.

[71] T. Ozel, Y. Karpat, L. Figueira, J.P. Davim, "Modelling of surface finish and tool flank wear in turning of AISI D2 steel with ceramic wiper inserts," J. Mater. Process. Technol., vol. 189, pp. 192-198, 2007.

[72] A.K. Gupta, Predictive modelling of turning operations using response surface methodology, artificial neural networks and support vector regression," Int. J. Product. Research, vol. 48, pp. 763-778, 2010.

[73] C.Y. Nian, W.H. Yang and Y.S. Tarng, "Optimization of turning operations with multiple performance characteristics," J. Mater. Process. Technol., vol, 95, pp. 90-96, 1999.

[74] J. P. Davim, "Design of optimization of for turning parameters for cutting metal matrix composites base on orthogonal arrays," J. Mater. Process. Technol., vol. 132, pp. 340-344, 2003.

[75] A. Manna and S. Salodkar, "Optimization of machining conditions for effective turning of E0300 alloy steel," J. Mater. Process. Technol., vol. 203, pp. 147-153, 2008.

[76] M. Nalbant, H. Gokkaya and G. Sur, "Application of Taguchi method in the optimization of cutting parameters for surface roughness in turning," Mater. Design, vol. 28, pp. 1379-1385, 2007.

[77] Aman Aggarwala,., Hari Singhb, Pradeep Kumarc, Manmohan Singhd, "Optimizing power consumption for CNC turned parts using response surface methodology and Taguchi's technique-a comparative analysis," J. Mater. Process. Technol., vol, 200, pp. 373-384, 2008.

[78] I. Asiltürk and S. Neseli, "Multi response optimisation of CNC turning parameters via Taguchi method-based response surface analysis," Measurement, vol. 45, pp. 785-794, 2012.
[79] R.Q. Sardinas, M.R. Santana and E.A. Brindis, "Genetic algorithm-based multi-objective optimization of cutting parameters in turning processes," Eng. Appl. Artif. Intellig., vol. 19, 127-133, 2006.

[80] D.M. Adona and R. Teti, "Genetic algorithm-based optimization of cutting parameters in turning processes," Proc. CIRP, vol. 7, pp. 323-328, 2013.

[81] N. Camuscu, "Effect of cutting speed on the performance of $\mathrm{Al}_{2} \mathrm{O}_{3}$ based ceramic tools in turning nodular cast iron," Mater. Design, vol. 27, pp. 997-1006, 2006. 